(C) 2020, The Authors. Published by Elsevier Inc. and Fass Inc. on behalf of the American Dairy Science Association ${ }^{\circledR}$. This is an open access article under the CC BY-NC-ND license (http://creativecommons.org/licenses/by-nc-nd/4.0/).

\title{
Phenotypic modeling of residual feed intake using physical activity and methane production as energy sinks
}

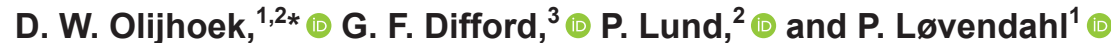 \\ ${ }^{1}$ Department of Molecular Biology and Genetics, Aarhus University Foulum, DK 8830 Tjele, Denmark \\ ${ }^{2}$ Department of Animal Science, Aarhus University Foulum, DK 8830 Tjele, Denmark \\ ${ }^{3}$ Department of Breeding and Genetics, Nofima AS, PO Box 210, N-1431 Ås, Norway
}

\begin{abstract}
Residual feed intake (RFI) is a measure of feed efficiency in dairy cattle. This study modeled phenotypic RFI of first- and second-parity Holstein and Jersey dairy cows within 9 lactation segments (consecutive segments of 4 wk each) covering the first 36 lactation weeks. We aimed to evaluate physical activity and daily methane production as additional energy sinks in the estimation of RFI, to examine the correlations of RFI among the first 36 wk of lactation (WOL), and to evaluate whether parities and breeds show similar results. Records for first-parity Holstein $(\mathrm{n}=449)$, second-parity Holstein $(\mathrm{n}=298)$, first-parity Jersey $(\mathrm{n}=195)$, and second-parity Jersey cows $(\mathrm{n}=146)$ were used. Model 1 included the following energy sinks: energy-corrected milk yield, metabolic body weight (BW), body condition score (BCS), daily changes in $\mathrm{BW}(\triangle \mathrm{BW})$ and BCS ( $\triangle \mathrm{BCS})$, and physical activity. Model 2 was based on a subset of the data and only for Holstein cows, and included the same energy sinks as Model 1, plus daily methane production. The trajectories of segmentspecific partial regression coefficients (PRC) of DMI on activity were similar across parities but differed slightly between breeds. For daily methane production, the trajectory in PRC decreased over lactation segments for first- and second-parity Holstein cows. The trajectories in PRC of DMI on energy-corrected milk yield, metabolic BW, BCS, and $\triangle \mathrm{BW}$ were generally similar across parities, except for $\triangle \mathrm{BCS}$. Activity accounted for on average $7.3,6.8,7.2$, and $6.4 \%$ of DMI for first-parity Holsteins, second-parity Holsteins, firstparity Jerseys, and second-parity Jerseys, respectively. Methane losses accounted for $8.7 \%$ and $8.5 \%$ of DMI for first- and second-parity Holstein cows, respectively. Repeatability estimates for RFI over 36 WOL for Model 1 were 0.63 for first-parity Holsteins, 0.65 for secondparity Holsteins, 0.76 for first-parity Jerseys, and 0.80
\end{abstract}

Received August 23, 2019.

Accepted March 17, 2020

*Corresponding author: Dana.Olijhoek@anis.au.dk for second-parity Jerseys. For Model 2, the estimates were 0.59 and 0.61 for first- and second-parity Holstein cows, respectively. Correlations of RFI between WOL varied in strength, with weak correlations for the first 2 to 3 WOL with other WOL. In conclusion, physical activity and daily methane production accounted for part of DMI, and RFI of dairy cattle is not the same trait throughout lactation.

Key words: residual feed intake, methane, activity, dairy cow

\section{INTRODUCTION}

Feed efficiency of dairy cattle has traditionally been expressed as feed conversion efficiency, which is defined as the amount of milk produced per unit of feed intake. However, this definition is a ratio trait, which is generally considered challenging to incorporate in selection indices. Residual feed intake (RFI) is an alternative expression of feed efficiency and is defined as the difference between observed and predicted DMI (Koch et al., 1963). Predicted DMI is obtained through multiple regression of DMI on energy sinks, such as ECM yield, metabolic body weight (MBW), and BCS. Other fixed effects having an influence on DMI, such as parity, breed, and cohort effects, should also be accounted for. For similar levels of energy sinks, animals eating less than the population average have negative RFI values and are deemed more efficient; whereas animals eating more than the average have positive RFI values and are judged less efficient. The residual term, RFI, is an accumulation of true feed efficiency, unknown sinks, and trait-recording and model-fitting errors (Berry and Crowley, 2013). This residual error part can contribute to a large fraction (41 to 47\%) of residual energy intake (Fischer et al., 2018b). By definition, any energy sink not adjusted for in the fixed part of the model is attributed to RFI, which is the residual of the model. Nutrition studies suggest that methane emission is a significant waste of feed energy, comprising 2.7 to $9.8 \%$ of gross energy intake of dairy cattle (Niu et al., 2018). Similarly, physical activity requires energy and 
thus may be considered an energy sink. These aspects may have consequences for RFI, depending on whether methane emission and physical activity are included in the model as sinks or ignored and thereby attributed to the random part (i.e., RFI). If physical activity levels between animals should remain unchanged, then they should be adjusted for in the model. If methane emissions need to be reduced, then they should be ignored in the model. Their importance as energy sinks or unwanted sinks requires investigation. Also of importance is the fetus, which becomes an increasing energy sink with advancing gestation and throughout lactation (NRC, 2001). Therefore, stage of gestation should not be ignored. Other energy sinks, such as ECM yield, BW, and BCS, vary over lactation due to mobilization and deposition of energy reserves (Mäntysaari et al., 2012). Different breeds are another aspect to consider when modeling RFI. There are indications that Holstein and Jersey cows differ in several energy-related processes, such as methane production and nutrient digestibility (Olijhoek et al., 2018).

Historically, RFI was first modeled using a 2-step procedure (Koch et al., 1963), where fixed effects were included in the first step and obtained residuals studied for genetic or other random effects in the second step or model. Alternatively, Tempelman et al. (2015) suggested a 1-step model, accounting simultaneously for fixed and random effects, thereby reducing standard errors on estimates of both fixed and random effects and minimizing the confounding of effects. However, modeling both energy sinks and random effects of RFI with repeated records over lactation requires special considerations. For example, changing DMI and ECM yield over lactation lead to varying partial regression coefficients (PRC) for energy sinks with lactation stage, which should not be ignored (Li et al., 2017). Equally important are the individual random cow solutions, which comprise a heritable genetic effect and a permanent environmental effect (Løvendahl et al., 2018). These individual random cow solutions denote RFI values in random regression, rather than the residuals from the model equation and would be of use in ranking cows for feed efficiency. Values for RFI are correlated but also change over lactation (Veerkamp et al., 2013). Therefore, it can be questioned whether RFI determined for a short period in lactation will reflect other stages of lactation, the whole lactation, or perhaps the following lactation.

In this study, we expand the regression model for phenotypic RFI by modeling individual-level random cow effects using Legendre polynomials (Manafiazar et al., 2013; Li et al., 2017) to better describe changes in random effects over lactation. We include methane production and physical activity as additional energy sinks in the model and evaluate their relation with DMI through examining PRC. All PRC of DMI on energy sinks were allowed to vary over lactation segments to examine how relationships evolve. We focus on the phenotypic modeling of RFI of first- and second-parity Holstein and Jersey dairy cows to evaluate if these findings correspond to previous findings in first parity Holstein cows by Li et al. (2017). The main aim of this study was to evaluate physical activity and daily methane production as energy sinks in the estimation of RFI. Along with this, we also examined the correlations of RFI among the first 36 wk of lactation (WOL) and evaluated whether parities and breeds are similar in the previously described aspects.

\section{MATERIALS AND METHODS}

\section{Design and Animals}

This cohort study involved the recording of individual phenotypic measurements for Danish Holstein and Danish Jersey lactating dairy cows in a loose housing system with 3 management groups according to breed at the research herd of the Danish Cattle Research Centre (Aarhus University Foulum, Tjele, Denmark). Individual data on DMI, milk yield, milk composition, BW, BCS, methane emission, and physical activity were recorded over lactation (305-d lactation) and over parities. Data used in the statistical analysis of this study were collected between January 2003 and March 2018 and is a compilation of standard feeding practices and experiments. This study focused on the first $36 \mathrm{WOL}$ of first- and second-parity cows. Feeding and recording procedures are as described by Bossen and Weisbjerg (2009) and are briefly outlined as follows.

\section{Data Collection}

Animals were fed ad libitum with partial mixed ration (PMR), which was offered 4 times each day. Animals also had free access to feed and water. Feed intake was recorded automatically using the Insentec Roughage Intake Control system (RIC, Insentec B.V., Marknesse, the Netherlands), and each feed bin was shared by approximately 2 cows. Dry matter content of PMR was determined on a weekly basis by ovendrying at $60^{\circ} \mathrm{C}$ for $48 \mathrm{~h}$ (AOAC International, 2000). Cows were also daily offered approximately $3 \mathrm{~kg}$ of concentrate when entering 1 of the 3 automatic milking systems (AMS; 1 AMS per management group; DeLaval International AB, Tumba, Sweden) for milking, and the amount of concentrate refusals was recorded when 
each cow exited the AMS. However, the standard concentrate allowance was exceeded in a few experiments, as reported by Henriksen et al. (2019), and, in any case, the actual allowance and refusals were recorded. Cows had voluntary access to the AMS for milking and were milked on average 2 to 3 times daily, with a maximum daily visit frequency of 6 . Milk yield was recorded at each visit to the AMS. Daily milk yield was calculated according to a modified version of the ICAR principle (Fogsgaard et al., 2015) before being averaged per WOL, as also used by Li et al. (2017). Milk samples were collected from every milking during 48 $\mathrm{h}$ each week using the XMS autosampler (DeLaval International) and measured for fat, protein, and lactose content using a CombiFoss (Foss, Hillerød, Denmark) at Eurofins (Vejen, Denmark). The AMS also contained a platform scale (Danvaegt, Hinnerup, Denmark) to measure BW automatically at milking. Body condition score was recorded biweekly by trained personnel, using a scale of 1 (very lean) to 5 (very fat) with 0.25 -unit intervals (Kristensen, 1986). In the feed bin of each AMS, non-dispersive infrared gas analyzers (sniffers) for methane (Guardian NG, Edinburgh Instruments Ltd., Livingston, UK) and carbon dioxide (Gascard, Edinburgh Instruments) were installed. Specifications and procedures for installation and calibration of the sensors are described by Difford et al. (2016). Methane measurements used in the statistical analysis of this study were continuously collected between July 2013 and October 2016. The sensors were calibrated every 3 mo at the latest and each time after maintenance or repairs of the system. Diagnostics were run weekly to monitor the system.

Cows were equipped with commercially available activity meters (DeLaval International; Løvendahl and Chagunda, 2010) attached to neckbands to measure physical activity. These activity meters are commercially used on-farm to detect episodes of high activity related to estrus. The activity meter measures acceleration in neck movement in all directions and generates an impulse above a certain threshold. These impulses are counted and defined as a proxy for activity, irrespective of the type of movement or behavior. The activity counts were summed for each hour and then per day. Physical activity data used in the statistical analysis of this study were collected between January 2003 and March 2018.

\section{Data Editing, Calculations, and Statistical Analyses}

The original database contained 99,987 records. Observations for DMI, milk yield, milk composition, and BW were averages for each WOL. Only first- and second-parity cows were included in the analysis. Further, the first 36 WOL were retained to cover early, mid-, and most of late lactation and to ensure enough records, while avoiding fetus growth as an energy sink. The energy requirement for pregnancy is assumed to be insignificant in the first $190 \mathrm{~d}$ of gestation and then increases from $190 \mathrm{~d}$ onwards (NRC, 2001). On Danish farms, the interval between calving to first insemination is approximately $80 \mathrm{~d}$ (Ismael et al., 2016). Thus, fetus growth will first become an energy sink at 270 DIM. This number of days is in agreement with the findings of Strandberg and Lundberg (1991), who found that pregnancy negatively affected milk yield from around 270 DIM or $160 \mathrm{~d}$ in gestation. Thirty-six WOL were used to obtain 9 lactation segments, each 4 wk in length.

Outliers for DMI, ECM, BW, BCS, and daily methane production were removed based on limits defined as \pm 4 standard deviation (SD) units from the mean (population mean within breed) and $\pm 5 \mathrm{SD}$ units from the population mean within breed for milk fat, protein, and lactose content. Outliers for physical activity were handled by setting data to "missing" if fewer than 10 counts over a whole day were recorded, to avoid days with a battery failure. Daily activity count was then averaged per week, and only averages based on 2 or more days were retained for analysis. A square root transformation of the activity data was needed to correct for skewness of the data and make the data approximately normally distributed. The number of records retained for each variable after filtering can be found in Tables 1 and 2. The number of records in the entire data set were, at maximum, 39,168 for each variable, corresponding to 1,088 lactations of $36 \mathrm{wk}(449,298$, 195, and 146 lactations for first-parity Holstein cows, second-parity Holstein cows, first-parity Jersey cows, and second-parity Jersey cows, respectively). All cows calved between January 2003 and June 2017, spread evenly within years. Data on methane emission were available for a subset of the data: 1,665 (135 lactations) and 1,284 observations (112 lactations) for first- and second-parity Holstein cows, respectively.

Dry matter intake was calculated from the amount of PMR consumed from the feed bins plus the amount of concentrate consumed in the AMS on DM basis. Energy-corrected milk yield $(3.14 \mathrm{MJ} / \mathrm{kg})$ was calculated from milk components, with lactose as lactose monohydrate, according to Sjaunja et al. (1991):

$$
\begin{aligned}
& \operatorname{ECM}(\mathrm{kg} / \mathrm{d})=\text { milk }(\mathrm{kg} / \mathrm{d}) \times\{[38.3 \times \text { fat }(\mathrm{g} / \mathrm{kg}) \\
& +24.2 \times \text { protein }(\mathrm{g} / \mathrm{kg})+15.71 \times \text { lactose }(\mathrm{g} / \mathrm{kg}) \\
& +20.7] / 3,140\} .
\end{aligned}
$$




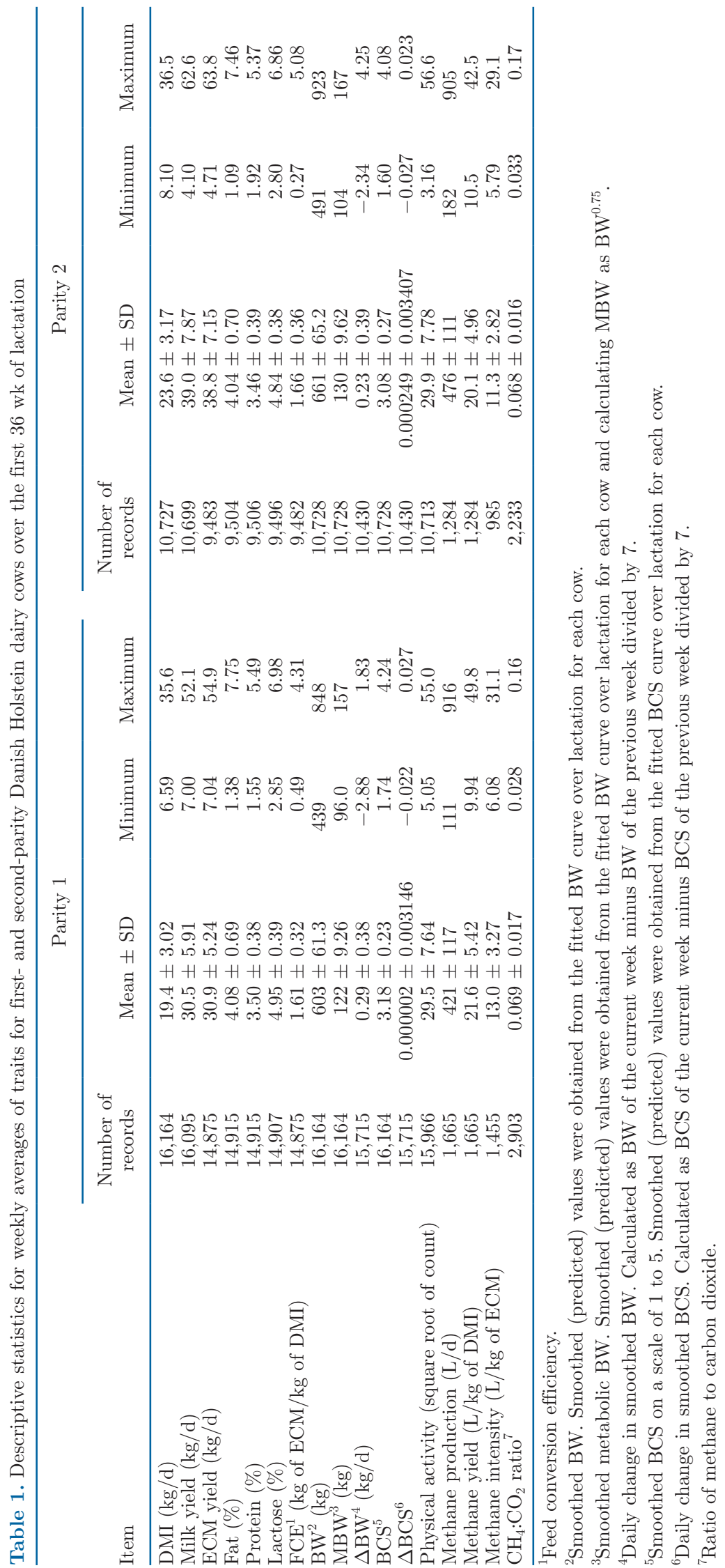




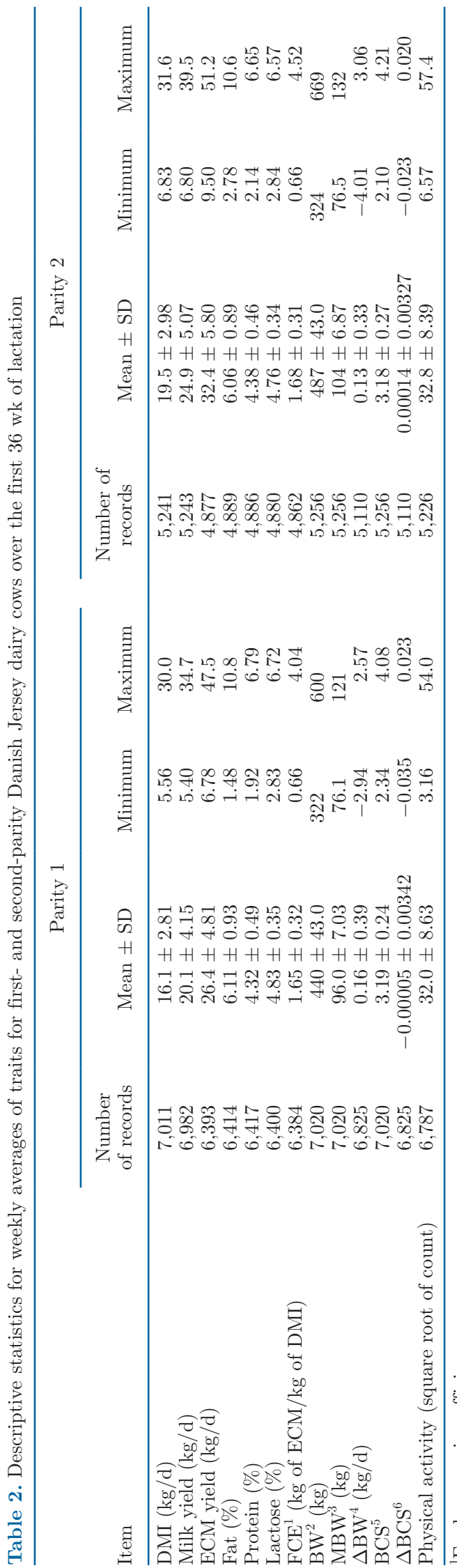

Data on daily methane production have been reported earlier by Zetouni et al. (2018). Daily methane production was calculated using carbon dioxide as a tracer gas and the $\mathrm{CH}_{4}: \mathrm{CO}_{2}$ ratio (Madsen et al., 2010). Briefly, this involves the following steps: first, heat-producing units (HPU) were calculated according to Madsen et al. (2010):

$$
\begin{gathered}
\operatorname{HPU}(\text { Watt })=5.6 \times \mathrm{BW}^{0.75}(\mathrm{~kg})+22 \\
\times \operatorname{ECM}(\mathrm{kg} / \mathrm{d})+1.6 \times 10^{-5} \times \text { days in pregnancy } .
\end{gathered}
$$

Second, Pedersen et al. (2008) recommended to use 180 L of carbon dioxide per HPU per hour; thus the predicted daily production of carbon dioxide is calculated as

$$
\text { Predicted } \mathrm{CO}_{2}(\mathrm{~L} / \mathrm{d})=\mathrm{HPU} \times 180(\mathrm{~L}) \times 24 .
$$

Last, daily methane production is calculated from the predicted carbon dioxide production and the $\mathrm{CH}_{4}$ : $\mathrm{CO}_{2}$ ratio, corrected for background air composition (Madsen et al., 2010) as follows:

$$
\mathrm{CH}_{4}(\mathrm{~L} / \mathrm{d})=\text { predicted } \mathrm{CO}_{2}(\mathrm{~L} / \mathrm{d})
$$

$\times$ [measured $\mathrm{CH}_{4}$ in air $(\mathrm{ppm})-$ measured $\mathrm{CH}_{4}$ in background air (ppm)]/[measured $\mathrm{CO}_{2}$ in air (ppm) - measured $\mathrm{CO}_{2}$ in background air (ppm)].

Like the other traits, methane production was averaged per WOL before being used in further analyses.

Daily changes in BW $(\Delta \mathbf{B W})$ and BCS $(\Delta \mathbf{B C S})$ were estimated by regressing BW and BCS on thirdorder Legendre polynomials on WOL (1 to 36), using PROC GLM in SAS version 9.3 (SAS Institute Inc., Cary, NC). Smoothed (predicted) values for BW and BCS were obtained from this model to reduce noise in the data. The difference between smoothed values for BW and BCS between 2 consecutive weeks (calculated as BW or BCS of the current week minus BW or BCS of the previous week) were divided by 7 to represent daily smoothed $\triangle \mathrm{BW}$ and $\triangle \mathrm{BCS}$. Within the $\triangle \mathrm{BW}$ and $\triangle \mathrm{BCS}$ variables, negative values represented a loss and positive values represented a gain in $\mathrm{BW}$ or $\mathrm{BCS}$, respectively.

Descriptive statistics of the data used to estimate RFI are presented in Tables 1 and 2. Residual feed intake was estimated in a 1-step procedure (Tempelman et al., 2015) using PROC MIXED in SAS. The DMI prediction equation for Model 1 was based on Li et al. (2017), using weekly averages for each sink and with the data being approximately normally distributed: 


$$
\begin{aligned}
& \operatorname{DMI}_{\mathrm{ijklmn}}(\mathrm{kg} / \mathrm{d})=\mu+\mathrm{b}_{1 \mathrm{i}} \mathrm{ECM}+\mathrm{b}_{2 \mathrm{i}} \mathrm{MBW}+\mathrm{b}_{3 \mathrm{i}} \mathrm{BCS} \\
& +\mathrm{b}_{4 \mathrm{i}} \Delta \mathrm{BW}+\mathrm{b}_{5 \mathrm{i}} \Delta \mathrm{BCS}+\mathrm{b}_{6 \mathrm{i}} \mathrm{ACT}+\mathrm{WOL}_{\mathrm{ij}}+\operatorname{cohort}_{\mathrm{k}} \\
& +\mathrm{YS}_{1}+\sum_{\mathrm{n}=0}^{3} \operatorname{cow}_{\mathrm{m}} \Phi_{\mathrm{n}}+\mathrm{e}_{\mathrm{ijklmn}},
\end{aligned}
$$

where $y_{i j k l m n}$ is the weekly observation of DMI in WOL $j$ $(\mathrm{j}=1$ to 36$)$ nested within lactation segment $\mathrm{i}(\mathrm{i}=1$ to 9) for cow $\mathrm{m}$, where cow $\mathrm{m}$ is in cohort $\mathrm{k}$ (management group assigned to the same dietary treatment; $\mathrm{k}=1$ to 62 for first-parity Holstein; $\mathrm{k}=1$ to 51 for secondparity Holstein; $\mathrm{k}=1$ to 46 for first-parity Jersey; and $\mathrm{k}=1$ to 43 for second-parity Jersey) in year-season (YS) 1 ( $1=1$ to 61 for first-parity Holstein cows, $1=1$ to 60 for second-parity Holstein cows, and $\mathrm{l}=1$ to 60 for all Jersey cows). Four seasons within a year were defined from March to May, June to August, September to November, and December to February. The intercept was defined as $\mu$, and $b_{1 i}, b_{2 i}, b_{3 i}, b_{4 i}, b_{5 i}$, and $b_{6 i}$ are fixed PRC within each lactation segment $i$ and for DMI on the following respective energy sinks: ECM yield, smoothed MBW, smoothed BCS, smoothed $\triangle B W$, smoothed $\triangle \mathrm{BCS}$, and the square root of the daily activity count (ACT). The random effect of cow $m$ was modeled with nth-order Legendre polynomials on WOL using an unstructured covariance structure; $\mathrm{cow}_{\mathrm{m}}$ are the random regression coefficients, and $\Phi_{\mathrm{n}}$ is the nth co-variable of the third-order Legendre polynomial for WOL. Estimates for RFI are the random cow solutions as Legendre polynomials up to the third order (RFI $=$ $\left.\Sigma \operatorname{cow}_{m} \Phi_{n}\right)$ and are assumed normally distributed with a mean of 0 . Last, e is the error term modeled with unstructured variances within the 9 lactation segments. Model 1 was applied to each breed and parity combination (4 runs) to allow covariance estimates to differ between breed and parity groups.

Model 2 was similar to Model 1, except that daily methane production $(\mathrm{L} / \mathrm{d})$ was included as an additional energy sink, and this model was made for a subset of the data only including Holstein cows. The terms in the model are similar to those of Model 1, but cohort $\mathrm{k}$ has 14 and 11 levels for first and second parity, respectively, and year-season 1 has 15 levels for each parity. The PRC of DMI on daily methane production is denoted by $b_{7}$. No collinearity was detected between the parameters used in Models 1 and 2.

Besides Models 1 and 2, 2 other models were constructed, to enable comparison of Models 1 and 2 to a model without activity (Model 0_ACT) or methane (Model 0_CH4, but with activity included) as respective sinks. Correlations between random solutions of these models were used to evaluate whether addition of these sinks affected RFI.
Partial regression coefficients were obtained from Models 1 and 2. Each PRC was compared with the constant partial regression coefficient (cPRC) over lactation, which was obtained from a model similar to Models 1 and 2 but ignoring lactation stage. A significant difference between $\mathrm{cPRC}$ and PRC was considered when the cPRC was outside the limits defined as \pm 1.96 standard error (SE) units from each segment-specific PRC.

The estimated covariance components of Models 1 and 2 were used with the Legendre polynomials to calculate individual cow variance, repeatability, and individual-level correlations (correlations between RFI estimates) over WOL 1 to 36 using the methodology of Fischer et al. (2004). The individual cow (co)variance matrices $\left(\sigma_{\text {cow }}^{2}\right)$ were estimated for each model using $\sigma_{\text {cow }}^{2}=\Phi \mathrm{K} \Phi^{\prime}$, where $\Phi$ is the matrix of orthogonal Legendre polynomial coefficients and $\mathrm{K}$ is the estimated covariance function describing the random regression coefficients.

The repeatability of RFI for Models 1 and 2 was estimated for each of the 36 WOL and modeled with third-order Legendre polynomials as

$$
\text { Repeatability }_{\mathrm{j}}=\frac{\sigma_{\text {cowj }}^{2}}{\sigma_{\text {cowj }}^{2}+\sigma_{\text {residualj }(i)}^{2}},
$$

where the repeatability is for WOL $\mathrm{j}(\mathrm{j}=1$ to 36$)$ and the residual variance for $\mathrm{j}$ is nested in lactation segment $\mathrm{i}(\mathrm{i}=1$ to 9 ). Similarly, the individual-level correlations $\left(\mathrm{r}_{\mathrm{I}}\right)$ between WOL $\mathrm{j}$, either within each breed $\times$ parity combination or between similar WOL of different models, were computed as

$$
\mathrm{r}_{\mathrm{Ij}}=\frac{\sigma_{\text {cowj } 1 \mathrm{j} 2}}{\sqrt{\sigma_{\text {cowj } 1}^{2}} \times \sqrt{\sigma_{\text {cowj } 2}^{2}}}
$$

where $\mathrm{r}_{\mathrm{Ij}}$ is the individual-level correlation coefficient

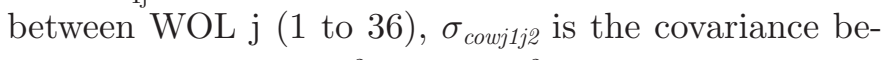
tween $2 \mathrm{WOL}$, and $\sigma_{\text {cowj } 1}^{2}$ and $\sigma_{\text {cowj } 2}^{2}$ are the variances for $\mathrm{j}$. Corresponding heat maps were created in $\mathrm{R}$ (version 3.6.1, R Core Team, 2019) using the gplots package (Warnes et al., 2019).

\section{RESULTS}

\section{Curves for DMI, Activity, and Methane During Lactation}

Levels of DMI, physical activity, and daily methane production depended on WOL (especially in early lac- 
tation), parity, and breed. Phenotypic means for DMI over 36 WOL increased from the beginning of lactation until approximately wk 10, after which DMI was relatively stable for both breeds and parities (Figure 1a). Dry matter intake was at a lower level for Jersey cows than for Holstein cows and for first-parity cows than for second-parity cows of both breeds (Tables 1 and 2; Figure 1a). Curves for physical activity over 36 WOL were similar in shape within parities and breeds (Figure 1b); however, they were at an elevated level for Jersey compared with Holstein and for second- compared with first-parity cows. The trajectory of the curves in daily methane production were similar for first- and secondparity Holstein cows (Figure 1c). For both curves, daily methane production was lowest at the beginning of lactation, increased gradually over the first weeks, and was relatively stable throughout the rest of lactation.

\section{Partial Regression Coefficients of DMI on Energy Sinks}

Nearly all terms included in the models had significant effects on DMI. Exceptions are for $\Delta \mathrm{BW}(P$ $=0.07)$ and $\triangle \mathrm{BCS}(P=0.07)$ in first-parity Jersey cows in Model 1, $\triangle \mathrm{BCS}(P=0.39)$ in second-parity Jersey cows in Model 1, activity $(P=0.89)$ in firstparity Holstein cows in Model 2 , and BCS $(P=0.08)$ in second-parity Holstein cows in Model 2.

The PRC of DMI on ECM (Figures 2a and 3a) and $\mathrm{MBW}$ (Figures $2 \mathrm{~b}$ and $3 \mathrm{~b}$ ) increased over the 9 lactation segments (4 wk each), with trajectories being similar for both parities and breeds. Trajectories in PRC of DMI on $\triangle \mathrm{BW}$ changed over lactation and between breeds (Figures 2c and 3c). Nearly all PRC of DMI on $\triangle \mathrm{BW}$ were positive and highest in early to midlactation for Holstein cows of both parities. For Jersey cows, a less clear pattern was visible in the trajectory of PRC over lactation segments, compared with Holstein cows (Figure 3c). The PRC of DMI on BCS decreased over lactation segments and had a similar trajectory for both parities of Holstein (Figure 2d) and Jersey cows (Figure 3d). The trajectory of the PRC of DMI on $\triangle \mathrm{BCS}$ was relatively stable for first-parity cows of both breeds over lactation segments, whereas the trajectory showed more fluctuations for second-parity cows (Figures $2 \mathrm{e}$ and $3 \mathrm{e}$ ).

The trajectory of the PRC of DMI on activity across lactation segments was similar across parities but differed slightly between breeds (Figures $2 \mathrm{f}$ and $3 \mathrm{f}$ ). The PRC for activity were similar in first- and second-parity Holstein cows, with higher PRC in lactation segment 1 compared with the cPRC over lactation $(0.048 \pm 0.004$ and $0.054 \pm 0.005 \mathrm{~kg}$ of DMI/unit of activity for firstparity and second-parity Holstein cows, respectively;
A
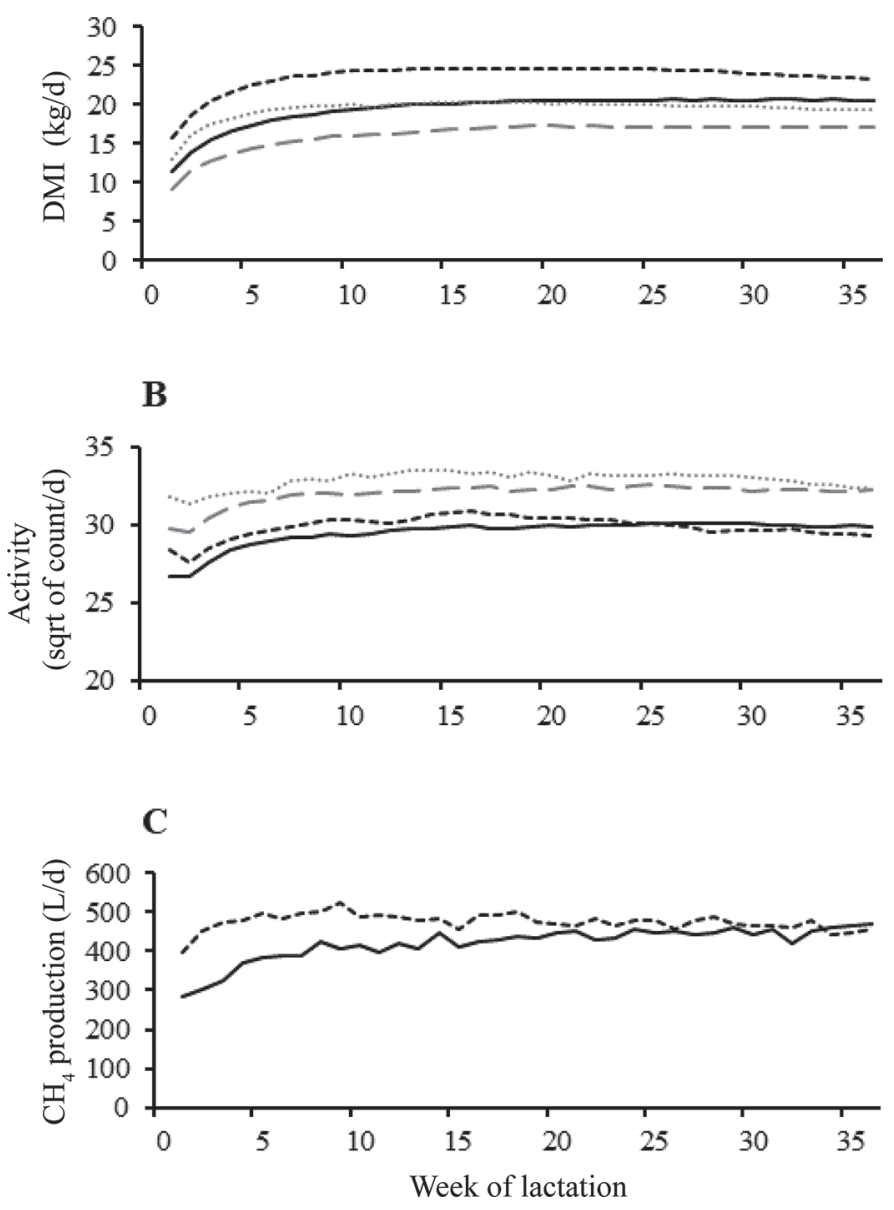

Figure 1. Mean values of DMI (A), physical activity (B), and daily methane production (C) for first- and second-parity Holstein and Jersey dairy cows over $36 \mathrm{wk}$ of lactation. Solid black line $=$ firstparity Holstein; short dashed black line = second-parity Holstein; long dashed gray line $=$ first-parity Jersey; dotted gray line = second-parity Jersey.

Figure 2f). For first-parity Jersey cows, the PRC of DMI on activity did not differ from the cPRC over lactation (0.036 $\pm 0.005 \mathrm{~kg}$ of $\mathrm{DMI} /$ unit of activity), whereas for second-parity Jersey cows the PRC of DMI on activity was higher than the cPRC $(0.038 \pm 0.007$ $\mathrm{kg}$ of DMI/unit of activity) in late lactation (Figure 3f). Together with the average activity levels and average DMI (Tables 1 and 2), these cPRC indicate that $7.3,6.8,7.2$, and $6.4 \%$ of DMI was utilized for activity for second-parity Holsteins, first-parity Jerseys, and second-parity Jerseys, respectively (e.g., for first-parity Holstein cows: $0.048 \mathrm{~g}$ of $\mathrm{DMI} /$ unit of activity $\times 29.5$ unit of activity $\div 19.4 \mathrm{~kg}$ of $\mathrm{DMI} / \mathrm{d} \times 100=7.3 \%$ of DMI).

The trajectory of the PRC of DMI on daily methane production (Model 2) of first-parity Holstein cows decreased over lactation segments (Figure 4). However, 
the PRC did not differ from the cPRC $(0.0040 \pm 0.0006$ $\mathrm{kg}$ of DMI/L of methane), except at lactation segment 8 and 9 . The PRC of DMI on daily methane production of second-parity Holstein cows did not differ from the cPRC $(0.0041 \pm 0.0009 \mathrm{~kg}$ of DMI/L of methane), except at lactation segment 1 . Methane losses contributed to 8.7 and $8.5 \%$ of DMI for first- and second-parity Holstein cows, respectively, as calculated from average daily methane production levels, average DMI (Tables 1 and 2), and cPRC (e.g., for first-parity Holstein cows: $0.0040 \mathrm{~g}$ of DMI/L of methane $\times 421 \mathrm{~L}$ of methane $\div$ $19.4 \mathrm{~kg}$ of $\mathrm{DMI} / \mathrm{d} \times 100=8.7 \%$ of $\mathrm{DMI})$.
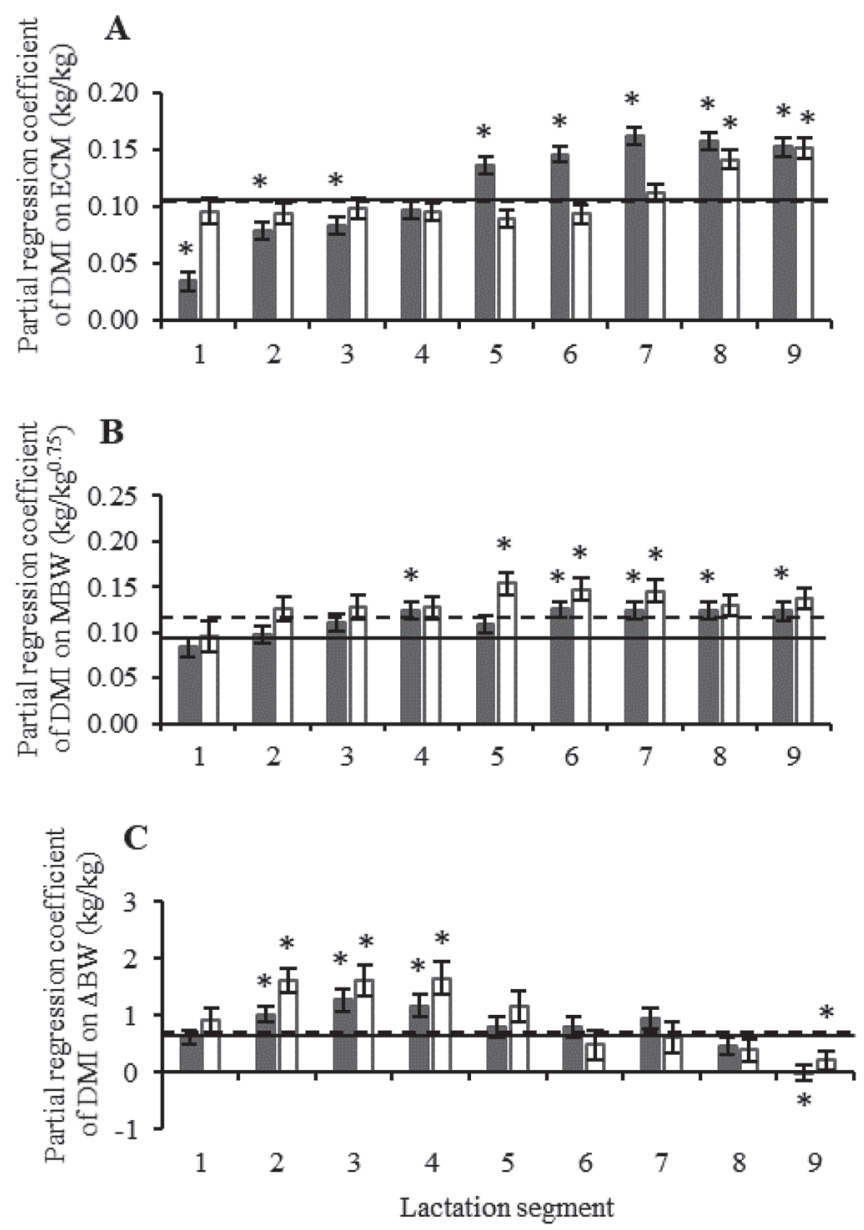

Repeatability, Residual Covariance, and IndividualLevel Correlations

The repeatability of RFI over lactation was similar between parities (Figures 5a and 5b) but higher for Jerseys than for Holsteins (Figure 5a). The average repeatability \pm SD of RFI over lactation for Model 1 was 0.63 \pm 0.080 for first-parity Holstein cows and $0.65 \pm 0.045$ for second-parity Holstein cows (Figure 5a). The average repeatability over lactation was greater for Jersey cows: $0.76 \pm 0.056$ for first and $0.80 \pm 0.045$ for second parity. The trajectories in repeatability over lactation
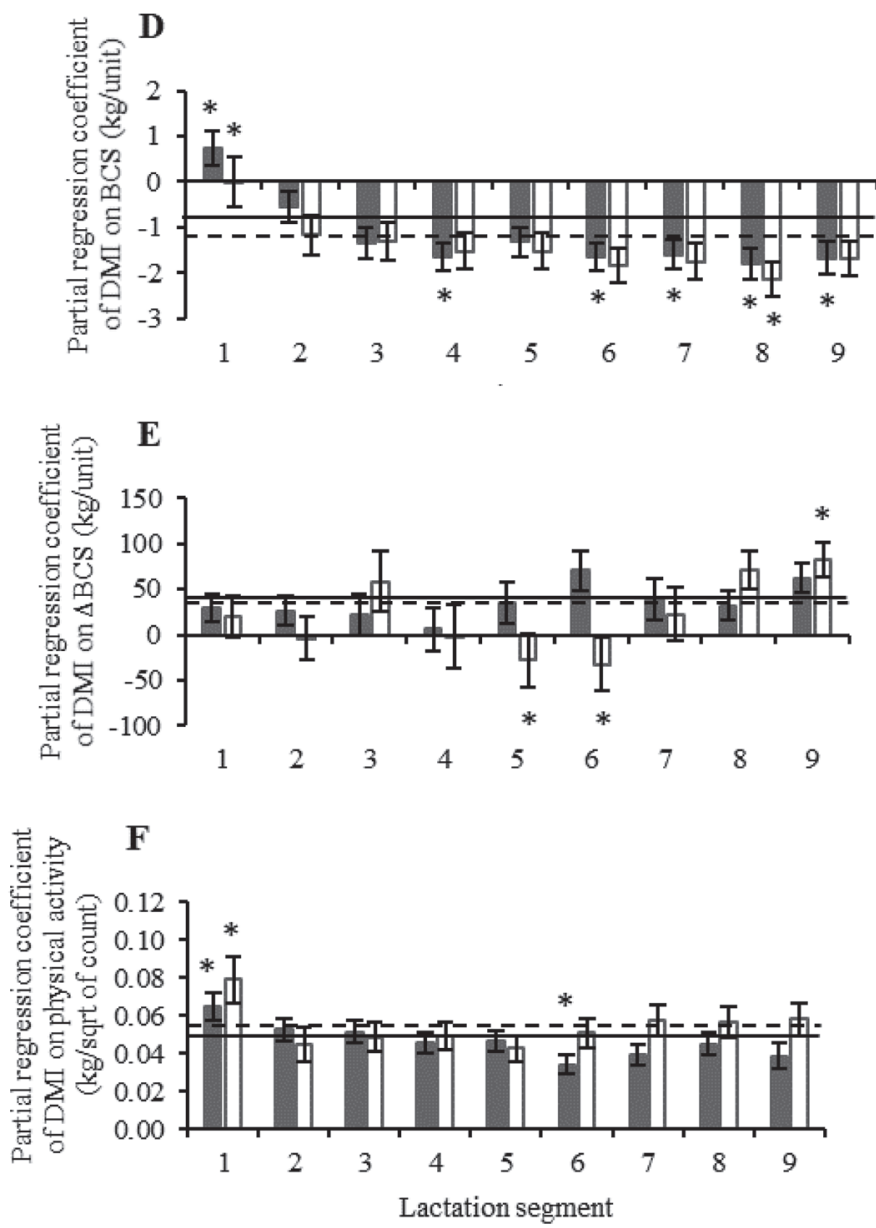

Figure 2. Partial regression coefficients of DMI on ECM yield (A); smoothed metabolic body weight (MBW; B); daily change in smoothed BW $(\Delta \mathrm{BW} ; \mathrm{C})$; smoothed BCS $(\mathrm{D})$; daily change in smoothed BCS $(\Delta \mathrm{BCS} ; \mathrm{E})$; and physical activity (F) for first- and second-parity Holstein dairy cows over the first $36 \mathrm{wk}$ of lactation divided over 9 lactation segments of $4 \mathrm{wk}$ each (segment $1=$ lactation wk 1 to $4,2=$ lactation wk 5 to 9, etc.) for Model 1. Gray bars are first-parity cows and white bars are second-parity cows. The horizontal lines represent the constant partial regression coefficient (cPRC) over the entire lactation, with the solid line representing first-parity cows and the dashed line second-parity cows. Asterisks at bars indicate a difference (limits of $\pm 1.96 \mathrm{SE}$ units) between the overall partial regression coefficient and partial regression coefficient for the specific lactation segment. Average $\pm \mathrm{SE}$ of cPRC for first- and second-parity Holstein cows, respectively, are $0.105 \pm 0.004$ and $0.105 \pm 0.004 \mathrm{~kg}$ of DMI $/ \mathrm{kg}$ of ECM, $0.093 \pm 0.007$ and $0.115 \pm 0.009 \mathrm{~kg}$ of DMI $/ \mathrm{kg}$ of MBW, $0.663 \pm 0.083$ and $0.701 \pm 0.122 \mathrm{~kg}$ of DMI $\mathrm{kg}$ of $\Delta \mathrm{BW},-0.772 \pm 0.201$ and $-1.192 \pm 0.264 \mathrm{~kg}$ of DMI/unit of BCS, $36.0 \pm 12.2$ and $37.8 \pm 8.77 \mathrm{~kg}$ of DMI/unit of $\Delta \mathrm{BCS}$, and $0.048 \pm$ 0.004 and $0.054 \pm 0.005 \mathrm{~kg}$ of DMI/unit of activity. 
were relatively similar between breeds and parities, but at an elevated level for Jersey than for Holstein cows and for second than for first parity. Repeatability estimates of RFI for Model 2 (Figure 5b) were slightly lower than for Model 1. Average repeatability estimates over lactation were $0.59 \pm 0.086$ for first-parity and $0.61 \pm 0.079$ for second-parity Holstein cows.

The residual covariance decreased upon including activity or daily methane production in the model. When including activity in the model (Model 1 vs. Model 0_ACT), the average reductions $\pm \mathrm{SD}$ in residual covariance across lactation segments were 0.015 $\pm 0.0086,0.025 \pm 0.0243,0.011 \pm 0.0152$, and $0.0138 \pm$ 0.0202 for first-parity Holstein, second-parity Holstein,
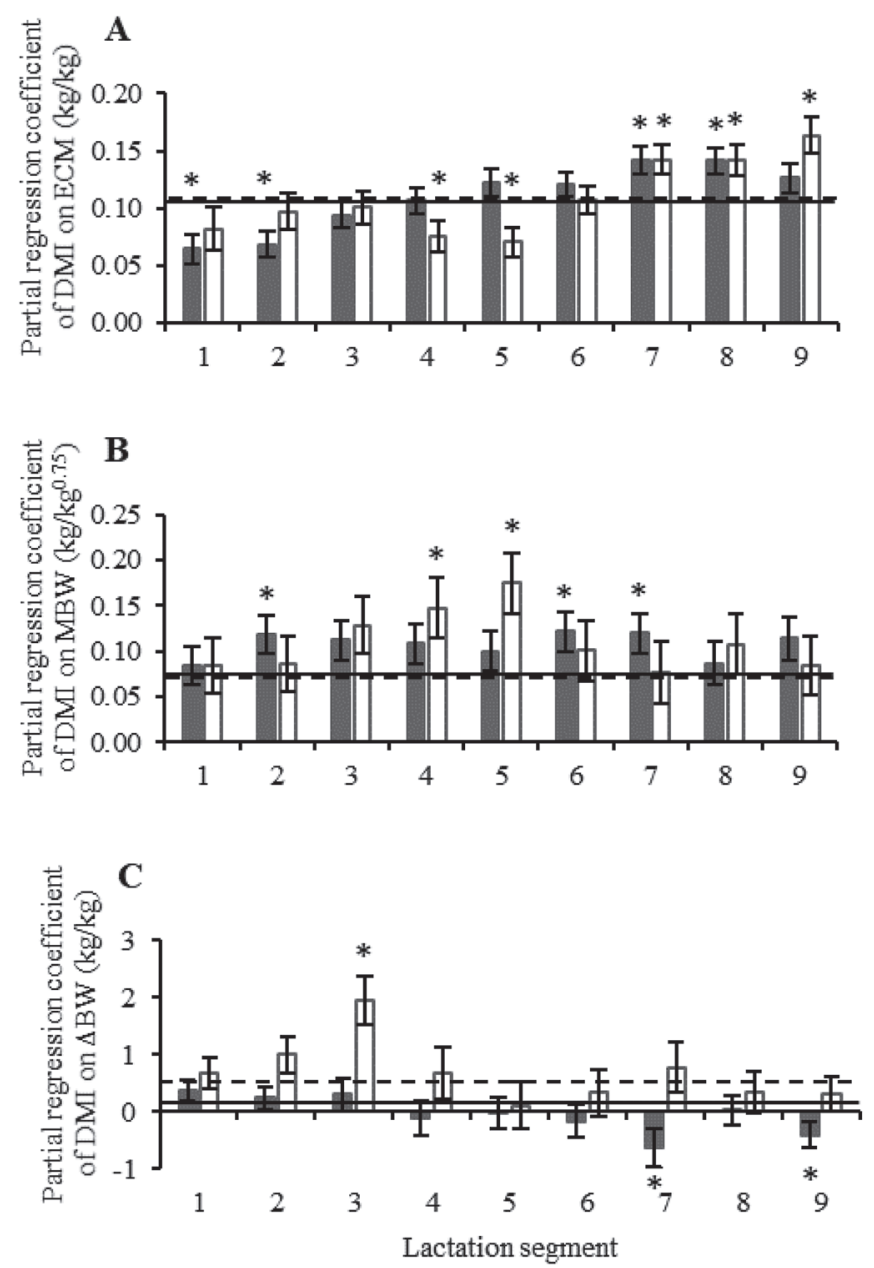

first-parity Jersey, and second-parity Jersey cows, respectively. In percentages, the reductions in residual covariance across lactation segments were, on average, $1.6 \pm 1.2 \%, 1.8 \pm 1.6 \%, 1.6 \pm 2.4 \%$, and $1.3 \pm 1.8 \%$ for first-parity Holstein, second-parity Holstein, first-parity Jersey, and second-parity Jersey cows, respectively. When including daily methane production in the model (Model 2 vs. Model 0_CH4), the average reductions across lactation segments were $0.011 \pm 0.0119$ and $0.042 \pm 0.1036$ and the average percentage reductions were $1.7 \pm 2.1 \%$ and $2.9 \pm 7.1 \%$ for first- and secondparity Holstein cows, respectively.

Individual-level correlations for RFI between each of the 36 WOL for breeds and parities were all positive
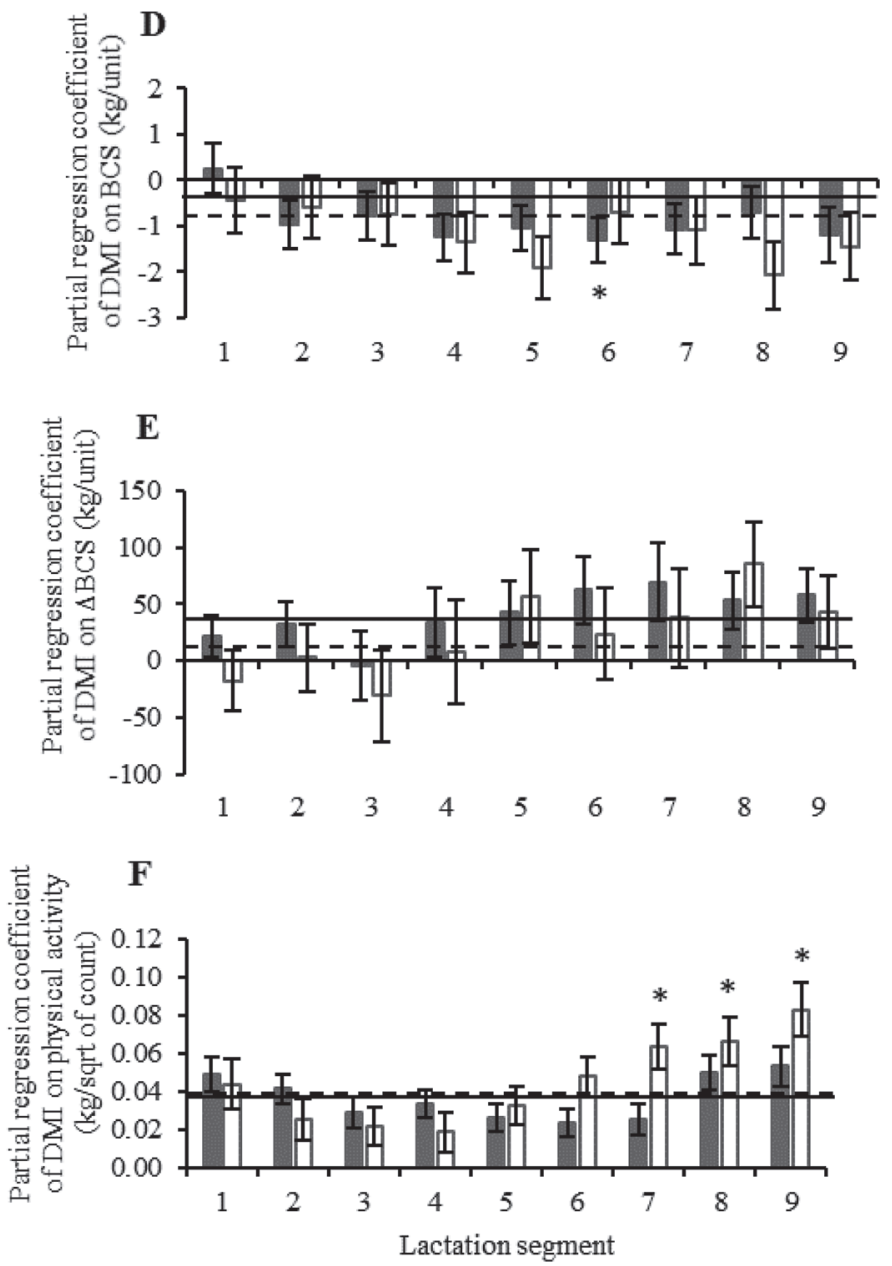

Figure 3. Partial regression coefficients (PRC) of DMI on ECM yield (A); smoothed metabolic body weight (MBW; B); daily change in smoothed BW $(\triangle \mathrm{BW} ; \mathrm{C})$; smoothed BCS (D); daily change in smoothed BCS ( $\triangle \mathrm{BCS} ; \mathrm{E})$; and physical activity $(\mathrm{F})$ for first- and second-parity Jersey dairy cows over the first $36 \mathrm{wk}$ of lactation divided over 9 lactation segments of 4 wk each (segment $1=$ lactation wk 1 to $4,2=$ lactation wk 5 to 9 , etc.) for Model 1. Gray bars are first-parity cows, and white bars are second-parity cows. The horizontal lines represent the regression coefficient over the whole lactation, with the solid line representing first-parity cows and the dashed line second-parity cows. Asterisks at bars indicate a difference (limits of $\pm 1.96 \mathrm{SE}$ units) between the overall PRC and PRC for the specific lactation segment. Average $\pm \mathrm{SE}$ of constant partial regression coefficient (cPRC) for first- and second-parity Jersey cows, respectively, are $0.106 \pm 0.006$ and $0.108 \pm 0.007 \mathrm{~kg}$ of $\mathrm{DMI} / \mathrm{kg}$ of ECM, $0.075 \pm 0.014$ and $0.073 \pm 0.021 \mathrm{~kg}$ of DMI $/ \mathrm{kg}$ of MBW, $0.132 \pm 0.116$ and $0.494 \pm 0.185 \mathrm{~kg}$ of DMI $/ \mathrm{kg}$ of $\Delta B W,-0.314 \pm 0.296$ and $-0.768 \pm 0.414 \mathrm{~kg}$ of DMI/unit of BCS, $38.3 \pm 11.1$ and $12.6 \pm 17.5 \mathrm{~kg}$ of DMI/unit of $\Delta \mathrm{BCS}$, and $0.036 \pm 0.005$ and $0.038 \pm 0.007 \mathrm{~kg}$ of DMI/unit of activity. 


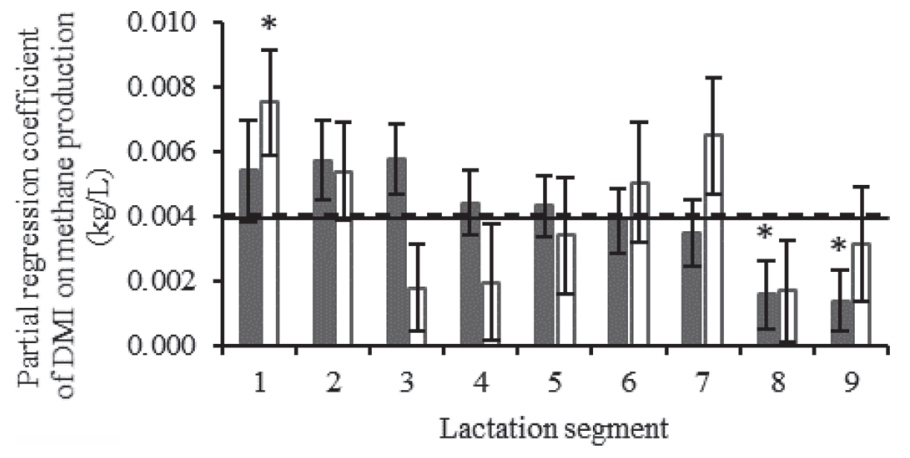

Figure 4. Partial regression coefficients (PRC) of DMI on daily methane production for first- and second-parity Holstein dairy cows over the first $36 \mathrm{wk}$ of lactation divided over 9 lactation segments of 4 wk each (segment $1=$ lactation wk 1 to $4,2=$ lactation wk 5 to 9, etc.) for Model 2. Gray bars are first-parity cows, and white bars are second-parity cows. The horizontal lines represent the regression coefficient over the whole lactation, with the solid line representing first-parity cows and the dashed line second-parity cows. Asterisks at bars indicate a difference (limits of $\pm 1.96 \mathrm{SE}$ units) between the overall PRC and PRC for the specific lactation segment. Average $\pm \mathrm{SE}$ of constant partial regression coefficient (cPRC) for first- and secondparity Holstein cows, respectively, are $0.0040 \pm 0.0006$ and $0.0041 \pm$ $0.0009 \mathrm{~kg}$ of $\mathrm{DMI} / \mathrm{L}$ of methane.

and were relatively similar between parities and breeds (Figure 6). The strength of the correlations differed throughout the lactation. The first 6 to10 WOL had a
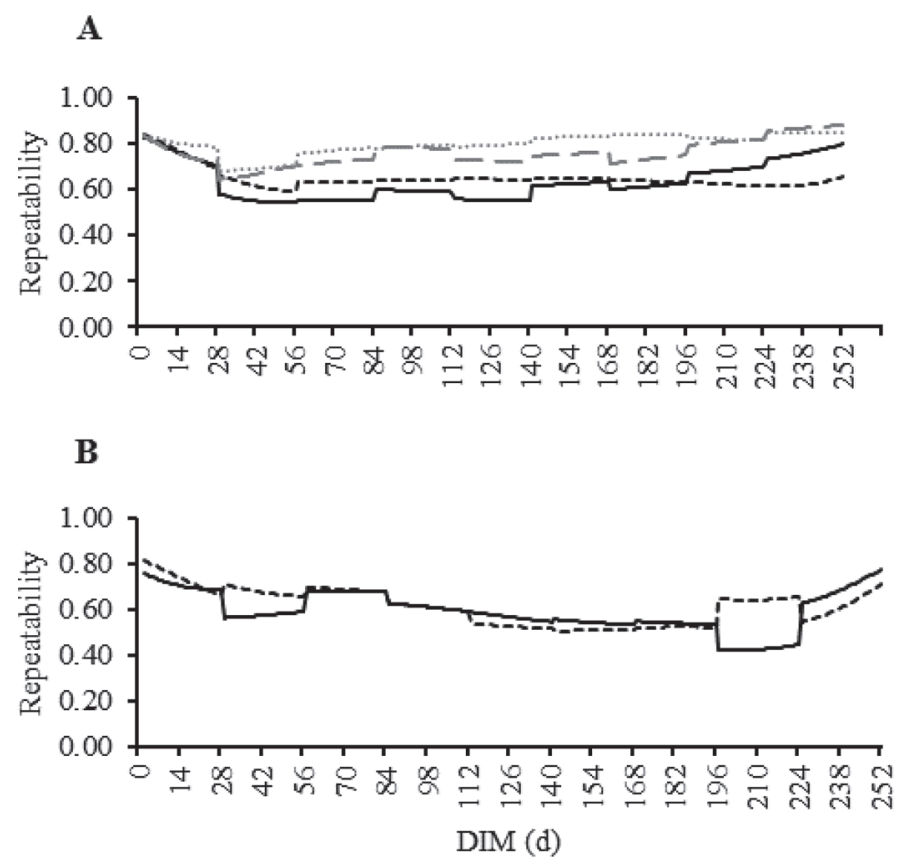

Figure 5. Repeatability for residual feed intake over 252 DIM (36 wk of lactation) for first- and second-parity Holstein and Jersey dairy cows for Model 1 including physical activity in the model (A) and firstand second-parity Holstein cows for Model 2 including physical activity and daily methane production in the model for a subset of the data set (B). Solid black line = first-parity Holstein; short dashed black line = second-parity Holstein; long dashed gray line = first-parity Jersey; dotted gray line $=$ second-parity Jersey. narrower window of strong correlations $\left(\mathrm{r}_{\mathrm{I}}>0.80\right)$ compared with the rest of lactation. Weak correlations $\mathrm{r}_{\mathrm{I}}<$ 0.20 were observed for the first 2 to $3 \mathrm{WOL}$ with other WOL. Between Model 1 and Model 0_ACT, average \pm SD for individual-level correlations for RFI at similar WOL were $0.97 \pm 0.009,0.97 \pm 0.006,0.98 \pm 0.010$, and $0.98 \pm 0.010$ for first-parity Holsteins, secondparity Holsteins, first-parity Jerseys, and second-parity Jerseys, respectively. For Model 2 and Model 0_CH4, the individual-level correlations were $0.96 \pm 0.010$ and $0.97 \pm 0.015$ for first- and second-parity Holstein cows, respectively.

\section{DISCUSSION}

\section{Energy Sinks for DMI}

Our study shows that physical activity, measured with neck tags (Model 1), and daily methane production, derived from sniffer measurements (Model 2), are likely energy sinks for DMI in dairy cattle. For instance, when expressing the percentage of DMI allocated to these sinks (ratios of means after correction for fixed and random effects), numbers ranged from 6.4 to $7.3 \%$ of DMI for activity, and were 8.7 and $8.5 \%$ of DMI for methane production for first- and secondparity Holstein cows, respectively. The inclusion of these sinks in the models (Model 1 vs. Model 0_ACT and Model 2 vs. Model 0_CH4) decreased the residual covariance, thereby improving the variance explained by the models. Moreover, including physical activity and daily methane production in the models had only minor effects on RFI, as demonstrated by the strong correlations between random solutions between models.

Another novel aspect of this study is the inclusion of third-order Legendre polynomials in the random part of the model, which is expected to better model the variances of phenotypic RFI for parts of lactation. Recently, Li et al. (2017) and Mehtiö et al. (2018) used regression within lactation segment as a way to account for changes in metabolic processes, which change over lactation, especially in early lactation. Trajectories in PRC of DMI on activity and daily methane production were rather stable over lactation and mostly not different from $\mathrm{cPRC}$ in contrast to other sinks (ECM, $\mathrm{MBW}, \mathrm{BCS}$, and $\triangle \mathrm{BW})$. Trajectories in PRC of DMI on energy sinks were generally similar between parities; however, significant differences between PRC and cPRC might occur at different lactation segments between parities. Moreover, breeds had similar trajectories for PRC of DMI on ECM, MBW, and BCS over lactation segments, although for some sinks (MBW, $\triangle \mathrm{BW}$, BCS, and $\triangle \mathrm{BCS}$ ) breed differences existed, as evaluated by the comparison of segment-specific PRC and cPRC 
A

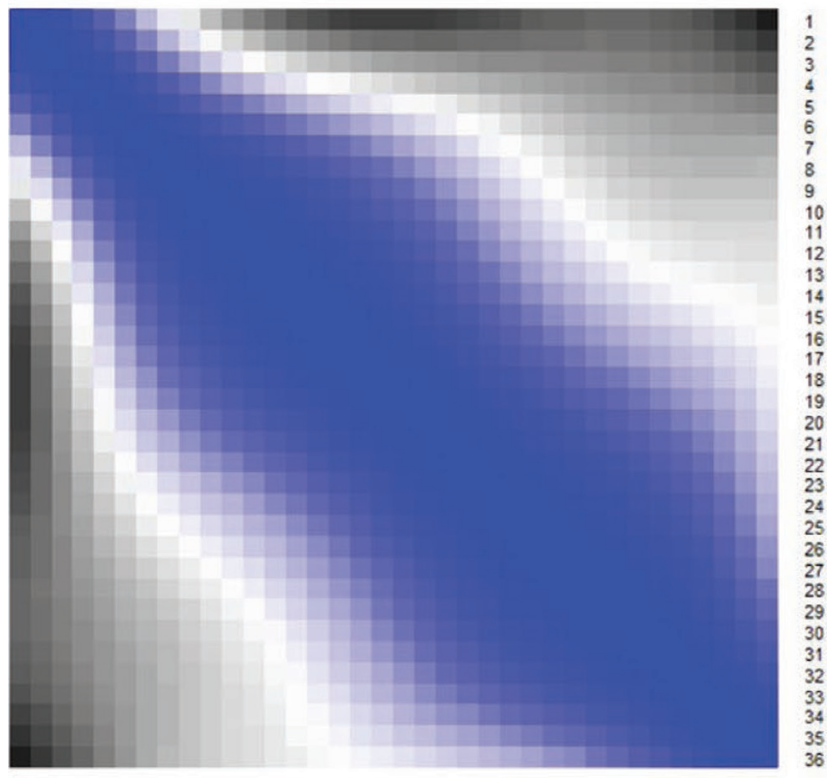

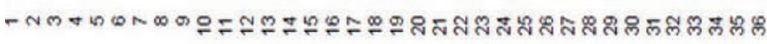

Color Key

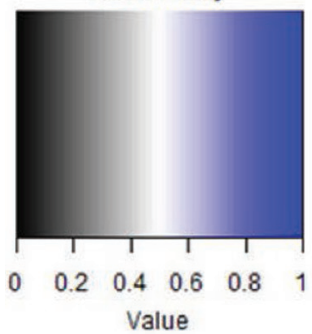

B

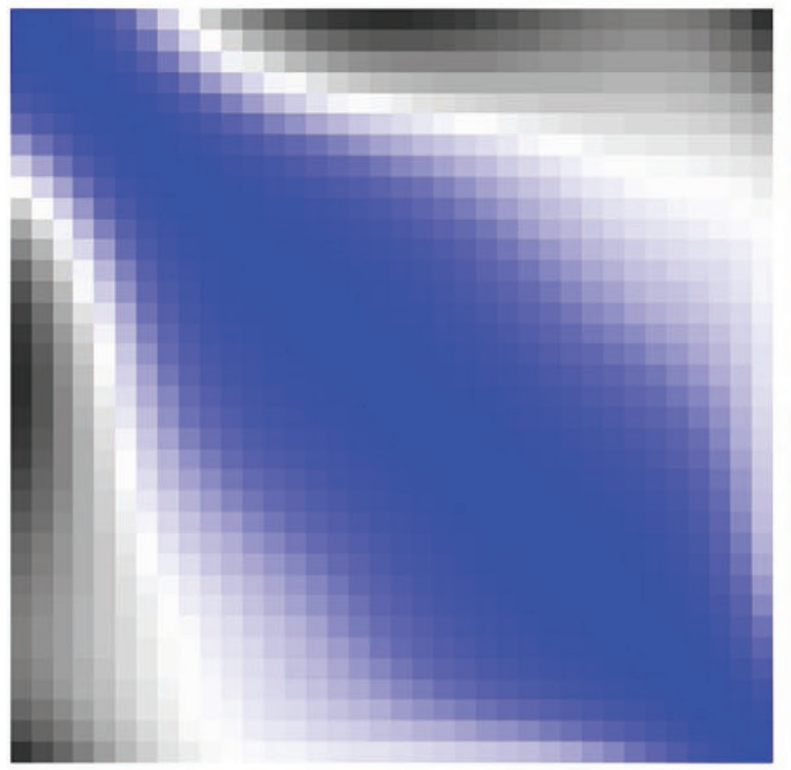

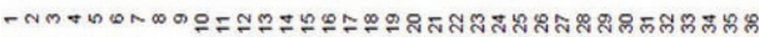

\section{C}

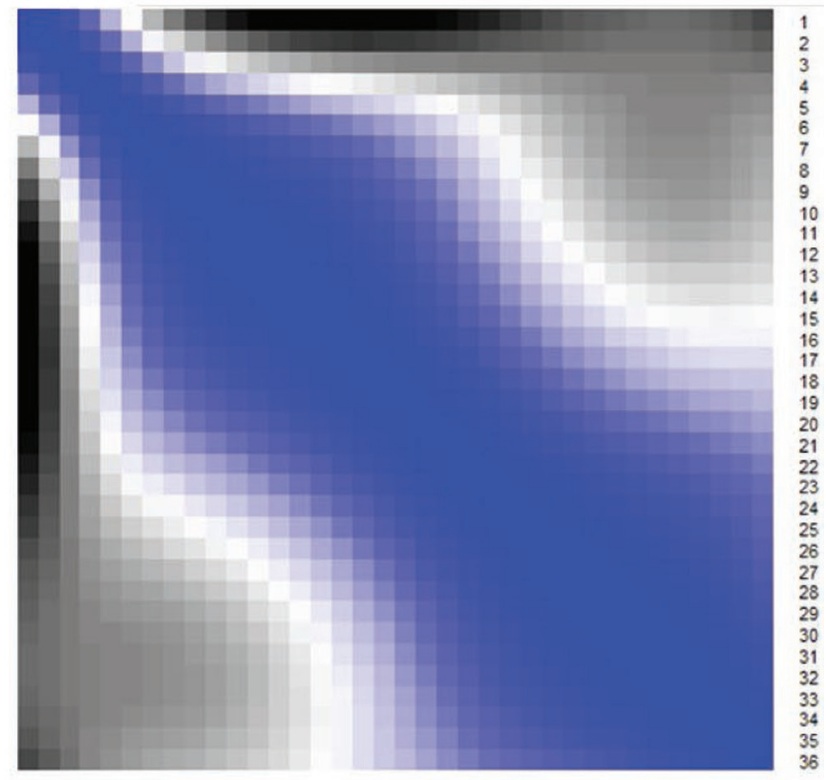

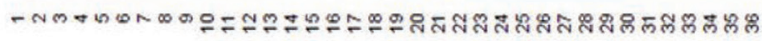

D

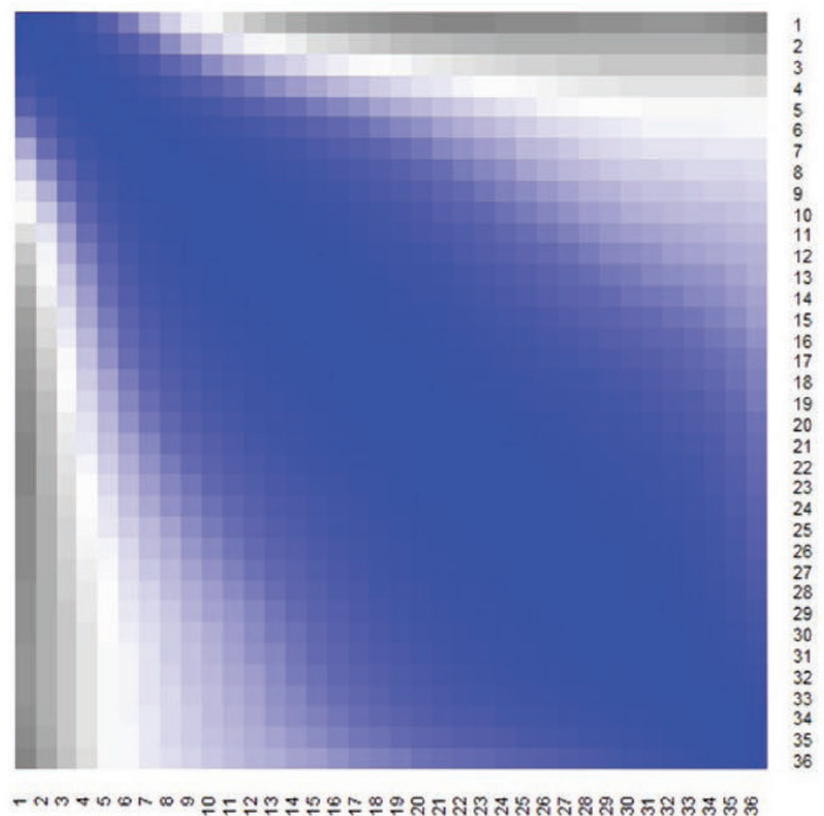

Figure 6. Individual-level correlations for residual feed intake between the first 36 wk of lactation for first- (A) and second-parity Holstein dairy cows (B), and first- (C) and second-parity Jersey dairy cows (D) for Model 1. 
for energy sinks. For these sinks, Holstein cows generally had more significant differences between PRC and cPRC than did Jersey cows. Additionally, PRC of DMI on physical activity were highest in early lactation for Holstein as opposed to late lactation for Jersey cows. Our study supports findings of $\mathrm{Li}$ et al. (2017) and Mehtiö et al. (2018) by showing that changing PRC of DMI on various energy sinks (i.e., ECM, MBW, BCS, and $\triangle \mathrm{BW}$, but not activity, daily methane production, and $\triangle \mathrm{BCS}$ ) over lactation, as compared with $\mathrm{cPRC}$, implies an under- or overestimation of RFI depending on lactation segment. These changing PRC and varying individual-level correlations for RFI between WOL within breed $\times$ parity combinations suggest that RFI is not the same trait throughout the first 36 WOL. Direct comparisons of PRC values between breeds and parities cannot be made, because they were modeled separately; however, trajectories of PRC over lactation segments were evaluated instead.

Curves for ECM and BW during lactation are not presented but were as expected and similar to $\mathrm{Li}$ et al. (2018) for first-parity Holstein and Jersey dairy cows. The curve for BCS was similar to those presented by Mäntysaari and Mäntysaari (2015). Curves for $\Delta B W$ and $\triangle \mathrm{BCS}$ were negative until approximately $10 \mathrm{WOL}$ and peaked between 20 and 30 WOL.

\section{Physical Activity}

The trajectory of PRC for physical activity was relatively stable over lactation segments, indicating that the amount of DMI allocated toward activity was comparable between segments, except for second-parity Jersey cows, for which the PRC increased in late lactation. This agrees with similar patterns between mean activity and DMI over 36 WOL. All PRC were positive, indicating that each unit increase in activity is associated with an increase in feed intake. However, it remains uncertain whether a higher feed intake resulted in a higher activity count, or whether a higher feed intake is required to fulfill the higher energy demand for activity. Nonetheless, high feed intake is a characteristic of high-RFI (i.e., inefficient) cows, and inefficient cows have been observed to be more active (Gregorini et al., 2015; Fischer et al., 2018a). Connor et al. (2013) also reported a weak positive phenotypic correlation $(\mathrm{r}=$ 0.13 ) between RFI and activity measured by pedometers, but this relation could not be confirmed within the same study by regressing pedometer readings on RFI. Perhaps physical activity could be a factor contributing to inefficiency due to a higher activity-related heat production, as has been reported for other animal species, such as poultry (Luiting et al., 1991) and pigs
(Barea et al., 2010). This relationship between RFI and activity has consequences when breeding for RFI. When activity is not included as an energy sink in the model, then breeding for low-RFI animals will result in less-active cows. On the contrary, including physical activity as an energy sink in the model makes activity independent of RFI by definition (in our models only within each lactation segment) and thereby activity levels similar between efficient and inefficient animals. Additionally, the cows in our experiment were housed indoors in a loose-housing system, and activity as energy sink will most likely be of higher importance for free-ranging grazing animals. Therefore, the decision to include physical activity as an energy sink in the model or not will depend on the specific farm system and breeding goal.

\section{Methane Production}

Daily methane production had a significant effect in Model 2 for Holstein cows and is therefore an energy sink for DMI. Each unit increase in daily methane production was associated with an increase in DMI, and the amount of DMI allocated toward methane was stable over lactation segments. The relationship between methane and DMI has been widely reported in literature (e.g., Niu et al., 2018; Zetouni et al., 2018); however, studies on the relationship between methane and RFI are more scarce. Experimental data suggests no difference in daily methane production between efficient and inefficient cows, although methane per kilogram of DMI has been found to be higher for efficient than for inefficient dairy cows (Olijhoek et al., 2018), dairy heifers (Flay et al., 2019), and beef heifers (McDonnell et al., 2016). This relationship could perhaps be related to digestibility, as a high feed intake increases the passage rate of feed material through the digestive tract and reduces the digestibility of fiber, especially (Colucci et al., 1982), and thereby reduces methane production. However, other large-scale studies showed a positive correlation between RFI and daily methane production (de Haas et al., 2011; Negussie et al., 2014). Despite these differing relationships reported in literature, including methane as an energy sink in the model makes daily methane production by definition uncorrelated with RFI, but only within each lactation segment. Through this, we demonstrated that methane losses accounted for 8.7 and $8.5 \%$ of DMI for first- and second-parity Holstein cows, respectively. For breeding purposes, however, it is required that methane is not included in the model, to allow variation between animals to exist and because a correlated response would be a decrease in methane emission. 


\section{ECM Yield}

The increasing PRC of DMI on ECM over lactation confirms findings by Mehtiö et al. (2018) for first-parity Nordic Red cows and by Li et al. (2017) for first-parity Holstein cows from the current research herd. Collectively, these findings indicate that it is incorrect to use overall cPRC for DMI on ECM over lactation, as this might lead to an under- or overestimation of RFI depending on lactation segment, except in mid-lactation when PRC are similar to cPRC. Our study also reports similar results for first-parity Jersey cows and second-parity cows of both breeds, though less evident for the latter. Moreover, increasing PRC over lactation segments indicate that an increasing amount of DMI is allocated toward ECM, possibly due to metabolic changes in early lactation.

\section{$B W$ and BCS}

The PRC of DMI on MBW were highest in mid- to late lactation for Holstein cows and in early to midlactation for Jersey cows. Our results contrast with those of Li et al. (2017), who reported that PRC were relatively stable and only higher in early lactation for first-parity Holstein cows, and with Mehtiö et al. (2018), who reported that PRC of DMI on MBW declined over lactation. Collectively, this implies a higher maintenance requirement at certain lactation stages, due to an increase in BW. Changes in BW suggest that some of the DMI is allocated to deposition of body reserves depending on lactation stage, and Mehtiö et al. (2018) reported that BW gain of primiparous Nordic Red cows was highest between wk 11 and 25. The increase in body reserves over lactation relates to the negative PRC of DMI on BCS (from lactation segment 2 onward) through the hormonal regulation of appetite by fat tissues. Breed differences in energy balance and tissue mobilization have been observed (Rastani et al., 2001; Friggens et al., 2007). Jersey cows have been observed to spend less time in negative energy balance in early lactation, with lower tissue losses than Holstein cows (Rastani et al., 2001). Collectively, these results suggest that differences exist in which stage of lactation deposition of energy reserves predominantly occurs and that these periods differ between parities and breeds.

\section{Repeatability of RFI and Correlations Within Lactation}

Repeatability estimates for both models were high, were similar between parities within breed, and reflect the conditions in this study (average repeatability for RFI over lactation is $0.63,0.65,0.76$, and 0.80 for first- parity Holsteins, second-parity Holsteins, first-parity Jerseys, and second-parity Jerseys, respectively). Our results agree with those of previous studies, for which repeatability estimates have been reported to be 0.77 for Holstein-Friesian, Jersey, and crossbred dairy cows over lactation (Prendiville et al., 2011), 0.47 within lactation for the first 90 DIM for Holstein dairy cows (Connor et al., 2013), and approximately 0.80 for Holstein dairy cows over 50 to 200 DIM (Tempelman et al., 2015). These estimates suggest that there is animal variation in RFI and some variation still unaccounted for in the DMI prediction model, despite the large number of sinks considered in Model 1, including physical activity. Repeatability increased slightly over the trajectory of lactation for first-parity Holstein and Jersey cows, and therefore average repeatability values over lactation do not reflect repeatability values at specific moments during lactation. Jersey cows also had higher repeatability estimates compared with Holstein cows, indicating more animal variation in RFI, either as additive genetic or permanent environment, for Jersey cows than for Holstein cows under the same farm management.

The varying strength in individual-level correlations for RFI between WOL indicates that RFI is not the same trait over lactation. Weeks closer together were strongly correlated, whereas weeks further apart are weakly or moderately correlated. These findings are in line with results of previous studies, where RFI in early lactation is only weakly or moderately phenotypically correlated with RFI in mid- and late lactation (Mäntysaari et al., 2012; Hurley et al., 2018) or whole-lactation efficiency (Prendiville et al., 2011). On a genetic level, correlations for RFI were negative between early and mid-lactation for first-parity Holstein cows (Li et al., 2017). However, varying correlations over lactation could also indicate inability to properly measure changes in metabolic status using indirect measures and over time, especially in early lactation, where changes occur rapidly.

\section{Implications}

The RFI approach was initially developed to rank cows for feed efficiency by adjusting feed intake for growth, milk yield, and maintenance, and was intended to be used in genetic selection. Further developments have shown that RFI changes over the lactation trajectory, partly because allocation of energy to different sinks also change. This complicates use of short-term records of DMI as a basis for RFI estimation, over and above the fact that DMI recording at large scale is still in its infancy. Future research should focus on the use of energy intake rather than DMI when studying energy 
sinks for the estimation of RFI, which is a limitation of the present study. Including more sinks, such as physical activity and especially methane production, in the RFI estimation shows that these traits will also have a desirable correlated response if RFI is phenotypically selected for. The decision to include or exclude physical activity as an energy sink in the model should be based on specific needs related to the farm system (e.g., loose housing or grazing system). However, it is not clear whether high or low activity has some desirable or undesirable side effects for other traits, including health or fertility. Regarding methane emission, more research should be performed on the relationship between RFI and methane. If this relationship appears favorable (i.e., lower methane emission for efficient animals), then methane emission should not be included as an energy sink in the model to facilitate breeding purposes, either as direct selection for low emissions or by indirect selection on RFI.

\section{CONCLUSIONS}

Physical activity and daily methane production were shown to be energy sinks for Holstein and Jersey dairy cows. These traits accounted for part of DMI and improved the model, although, when including these sinks in the model, their effect on RFI was small. Residual feed intake of dairy cattle is not the same trait throughout lactation, which may reflect the strong effects of energy mobilization during early lactation or inaccuracies in modeling the metabolic status of cows over lactation. This warrants the modeling of traditional energy sinks and RFI within lactation segment.

\section{ACKNOWLEDGMENTS}

The authors thank the staff at the Danish Cattle Research Centre (Aarhus University Foulum, Tjele, Denmark) for the daily care of animals. This study was funded by the Danish Milk Levy Fund (Aarhus, Denmark) and was part of the project Feed Utilization in Nordic Cattle (FUNC), which was a collaboration between Denmark, Finland, Norway, and Sweden. The authors have not stated any conflicts of interest.

\section{REFERENCES}

AOAC International. 2000. AOAC Official Methods of Analysis. 17th ed. Association of Official Agricultural Chemists, Washington, DC.

Barea, R., S. Dubois, H. Gilbert, P. Sellier, J. van Milgen, and J. Noblet. 2010. Energy utilization in pigs selected for high and low residual feed intake. J. Anim. Sci. 88:2062-2072. https://doi.org/ 10.2527/jas.2009-2395.

Berry, D. P., and J. J. Crowley. 2013. Cell Biology Symposium: Genetics of feed efficiency in dairy and beef cattle. J. Anim. Sci 91:1594-1613. https://doi.org/10.2527/jas.2012-5862.
Bossen, D., and M. R. Weisbjerg. 2009. Allocation of feed based on individual dairy cow live weight changes II: Effect on milk production. Livest. Sci. 126:273-285. https://doi.org/10.1016/j.livsci 2009.07.011.

Colucci, P. E., L. E. Chase, and P. J. Van Soest. 1982. Feed intake, apparent diet digestibility, and rate of particulate passage in dairy cattle. J. Dairy Sci. 65:1445-1456. https://doi.org/10.3168/jds .S0022-0302(82)82367-9.

Connor, E. E., J. L. Hutchison, H. D. Norman, K. M. Olson, C. P. Van Tassell, J. M. Leith, and R. L. Baldwin VI.. 2013. Use of residual feed intake in Holsteins during early lactation shows potential to improve feed efficiency through genetic selection. J. Anim. Sci. 91:3978-3988. https://doi.org/10.2527/jas.2012-5977.

de Haas, Y., J. J. Windig, M. P. L. Calus, J. Dijkstra, M. de Haan, A. Bannink, and R. F. Veerkamp. 2011. Genetic parameters for predicted methane production and potential for reducing enteric emissions through genomic selection. J. Dairy Sci. 94:6122-6134. https://doi.org/10.3168/jds.2011-4439.

Difford, G. F., J. Lassen, and P. Løvendahl. 2016. Interchangeability between methane measurements in dairy cows assessed by comparing precision and agreement of two non-invasive infrared methods. Comput. Electron. Agric. 124:220-226. https://doi.org/10.1016/j .compag.2016.04.010.

Fischer, A., R. Delagarde, and P. Faverdin. 2018a. Identification of biological traits associated with differences in residual energy intake among lactating Holstein cows. J. Dairy Sci. 101:4193-4211. https://doi.org/10.3168/jds.2017-12636.

Fischer, A., N. C. Friggens, D. P. Berry, and P. Faverdin. 2018b. Isolating the cow-specific part of residual energy intake in lactating dairy cows using random regressions. Animal 12:1396-1404. https: //doi.org/10.1017/S1751731117003214.

Fischer, T. M., A. R. Gilmour, and J. H. J. van der Werf. 2004. Computing approximate standard errors for genetic parameters derived from random regression models fitted by average information REML. Genet. Sel. Evol. 36:363-369. https://doi.org/10 .1186/1297-9686-36-3-363.

Flay, H. E., B. Kuhn-Sherlock, K. A. Macdonald, M. Camara, N. Lopez-Villalobos, D. J. Donaghy, and J. R. Roche. 2019. Hot topic: Selecting cattle for low residual feed intake did not affect daily methane production but increased methane yield. J. Dairy Sci. 102:2708-2713. https://doi.org/10.3168/jds.2018-15234.

Fogsgaard, K. K., P. Løvendahl, T. W. Bennedsgaard, and S. Østergaard. 2015. Changes in milk yield, lactate dehydrogenase, milking frequency, and interquarter yield ratio persist for up to 8 weeks after antibiotic treatment of mastitis. J. Dairy Sci. 98:7686-7698. https://doi.org/10.3168/jds.2014-9204.

Friggens, N. C., P. Berg, P. Theilgaard, I. R. Korsgaard, K. L. Ingvartsen, P. L. Løvendahl, and J. Jensen. 2007. Breed and parity effects on energy balance profiles through lactation: Evidence for genetically driven body reserve change. J. Dairy Sci. 90:5291-5305. https://doi.org/10.3168/jds.2007-0173.

Gregorini, P., G. C. Waghorn, B. Kuhn-Sherlock, A. J. Romera, and K. A. Macdonald. 2015. Short communication: Grazing pattern of dairy cows that were selected for divergent residual feed intake as calves. J. Dairy Sci. 98:6486-6491. https://doi.org/10.3168/jds .2015-9614.

Henriksen, J. C. S., M. R. Weisbjerg, P. Løvendahl, T. Kristensen, and L. Munksgaard. 2019. Effects of an individual cow concentrate strategy on production and behavior. J. Dairy Sci. 102:2155-2172. https://doi.org/10.3168/jds.2018-15477.

Hurley, A. M., N. López-Villalobos, S. McParland, E. Lewis, E. Kennedy, M. O'Donovan, J. L. Burke, and D. P. Berry. 2018. Characteristics of feed efficiency within and across lactation in dairy cows and the effect of genetic selection. J. Dairy Sci. 101:1267-1280. https://doi.org/10.3168/jds.2017-12841.

Ismael, A., E. Strandberg, B. Berglund, M. Kargo, A. Fogh, and P. Løvendahl. 2016. Genotype by environment interaction for the interval from calving to first insemination with regard to calving month and geographic location in Holstein cows in Denmark and Sweden. J. Dairy Sci. 99:5498-5507. https://doi.org/10.3168/jds .2015-10820. 
Koch, R. M., L. A. Swiger, D. Chambers, and K. E. Gregory. 1963. Efficiency of feed use in beef cattle. J. Anim. Sci. 22:486-494. https: //doi.org/10.2527/jas1963.222486x.

Kristensen, T. 1986. Method for estimation of body condition of dairy cows. Page 16 in Research in Cattle Production Systems. National Institute of Animal Science Report 615. V. Østergaard and J. Hindhede, ed. Frederiksberg Bogtrykkeri, Copenhagen, Denmark.

Li, B., B. Berglund, W. F. Fikse, J. Lassen, M. H. Lidauer, P. Mäntysaari, and P. Løvendahl. 2017. Neglect of lactation stage leads to naive assessment of residual feed intake in dairy cattle. J. Dairy Sci. 100:9076-9084. https://doi.org/10.3168/jds.2017-12775.

Li, B., W. F. Fikse, P. Løvendahl, J. Lassen, M. H. Lidauer, P. Mäntysaari, and B. Berglund. 2018. Genetic heterogeneity of feed intake, energy-corrected milk, and body weight across lactation in primiparous Holstein, Nordic Red, and Jersey cows. J. Dairy Sci. 101:10011-10021. https://doi.org/10.3168/jds.2018-14611.

Løvendahl, P., and M. G. G. Chagunda. 2010. On the use of physical activity monitoring for estrus detection in dairy cows. J. Dairy Sci. 93:249-259. https://doi.org/10.3168/jds.2008-1721.

Løvendahl, P., G. F. Difford, B. Li, M. G. G. Chagunda, P. Huhtanen, M. H. Lidauer, J. Lassen, and P. Lund. 2018. Review: Selecting for improved feed efficiency and reduced methane emissions in dairy cattle. Animal 12(Suppl. 2):s336-s349. https://doi.org/10.1017/ S1751731118002276.

Luiting, P., J. W. Schrama, W. van der Hel, and E. M. Urff. 1991. Metabolic differences between white leghorns selected for high and low residual food consumption. Br. Poult. Sci. 32:763-782. https:/ /doi.org/10.1080/00071669108417402.

Madsen, J., B. S. Bjerg, T. Hvelplund, M. R. Weisbjerg, and P. Lund. 2010. Methane and carbon dioxide ratio in excreted air for quantification of the methane production from ruminants. Livest. Sci. 129:223-227. https://doi.org/10.1016/j.livsci.2010.01.001.

Manafiazar, G., T. McFadden, L. Goonewardene, E. Okine, J. Basarab, P. Li, and Z. Wang. 2013. Prediction of residual feed intake for first-lactation dairy cows using orthogonal polynomial random regression. J. Dairy Sci. 96:7991-8001. https://doi.org/10.3168/ jds.2013-6560.

Mäntysaari, P., A.-E. Liinamo, and E. A. Mäntysaari. 2012. Energy efficiency and its relationship with milk, body, and intake traits and energy status among primiparous Nordic Red dairy cattle. J. Dairy Sci. 95:3200-3211. https://doi.org/10.3168/jds.2011-4685.

Mäntysaari, P., and E. A. Mäntysaari. 2015. Modeling of daily body weights and body weight changes of Nordic Red cows. J. Dairy Sci. 98:6992-7002. https://doi.org/10.3168/jds.2015-9541.

McDonnell, R. P., K. J. Hart, T. M. Boland, A. K. Kelly, M. McGee, and D. A. Kenny. 2016. Effect of divergence in phenotypic residual feed intake on methane emissions, ruminal fermentation, and apparent whole-tract digestibility of beef heifers across three contrasting diets. J. Anim. Sci. 94:1179-1193. https://doi.org/10 $.2527 /$ jas.2015-0080.

Mehtiö, T., E. Negussie, P. Mäntysaari, E. A. Mäntysaari, and M. H. Lidauer. 2018. Genetic background in partitioning of metabolizable energy efficiency in dairy cows. J. Dairy Sci. 101:4268-4278. https://doi.org/10.3168/jds.2017-13936.

Negussie, E., P. Mäntysaari, E. A. Mäntysaari, and M. Lidauer. 2014. Animal wise variation in enteric methane output traits and its relationships with feed efficiency in dairy cattle: A longitudinal model analysis. Proc. 10th World Congr. Genet. Appl. Livest. Prod., Vancouver, Canada. Am. Soc. Anim. Sci., Champaign, IL.

Niu, M., E. Kebreab, A. N. Hristov, J. Oh, C. Arndt, A. Bannink, A. R. Bayat, A. F. Brito, T. Boland, D. Casper, L. A. Crompton, J. Dijkstra, M. A. Eugène, P. C. Garnsworthy, M. N. Haque, A. L. F. Hellwing, P. Huhtanen, M. Kreuzer, B. Kuhla, P. Lund, J. Madsen, C. Martin, S. C. McClelland, M. McGee, P. J. Moate, S. Muetzel, C. Muñoz, P. O'Kiely, N. Peiren, C. K. Reynolds, A. Schwarm, K. J. Shingfield, T. M. Storlien, M. R. Weisbjerg, D. R. Yáñez-Ruiz, and Z. Yu. 2018. Prediction of enteric methane production, yield, and intensity in dairy cattle using an intercontinental database. Glob. Chang. Biol. 24:3368-3389. https://doi .org/10.1111/gcb.14094.

NRC. 2001. Energy. Pages 13-27 in Nutrient Requirements of Dairy Cattle. 7th rev. ed. National Academy Press, Washington, DC.

Olijhoek, D. W., P. Løvendahl, J. Lassen, A. L. F. Hellwing, J. K. Höglund, M. R. Weisbjerg, S. J. Noel, F. McLean, O. Højberg, and P. Lund. 2018. Methane production, rumen fermentation, and diet digestibility of Holstein and Jersey dairy cows being divergent in residual feed intake and fed at 2 forage-to-concentrate ratios. J. Dairy Sci. 101:9926-9940. https://doi.org/10.3168/jds.2017-14278.

Pedersen, S., V. Blanes-Vidal, H. Joergensen, A. Chwalibog, A. Haeussermann, M. J. W. Heetkamp, and A. J. A. Aarnink. 2008. Carbon dioxide production in animal houses: A literature review. Agric. Eng. Int.: CIGR Ejournal Manuscript BC 08 008, Vol. X. December.

Prendiville, R., K. M. Pierce, L. Delaby, and F. Buckley. 2011. Animal performance and production efficiencies of Holstein-Friesian, Jersey and Jersey $\times$ Holstein-Friesian cows throughout lactation. Livest. Sci. 138:25-33. https://doi.org/10.1016/j.livsci.2010.11.023.

R Core Team. 2019. R: A language and environment for statistical computing. R Foundation for Statistical Computing, Vienna, Austria. https://www.R-project.org/.

Rastani, R. R., S. M. Andrew, S. A. Zinn, and C. J. Sniffen. 2001. Body composition and estimated tissue energy balance in Jersey and Holstein cows during early lactation. J. Dairy Sci. 84:12011209. https://doi.org/10.3168/jds.S0022-0302(01)74581-X.

Sjaunja, L. O., L. Baevre, L. Junkkarinen, J. Pedersen, and J. Setala. 1991. A Nordic proposal for an energy corrected milk (ECM) formula. Pages 156-157 in EAAP Publication 50: Performance recording of animals: State of the art 1990. Performance Centre for Agricultural Publishing and Documentation (PUDOC), Wageningen, the Netherlands.

Strandberg, E., and C. Lundberg. 1991. A note on the estimation of environmental effects on lactation curves. Anim. Prod. 53:399-402. https://doi.org/10.1017/S0003356100020420.

Tempelman, R. J., D. M. Spurlock, M. Coffey, R. F. Veerkamp, L. E. Armentano, K. A. Weigel, Y. de Haas, C. R. Staples, E. E. Connor, Y. Lu, and M. J. VandeHaar. 2015. Heterogeneity in genetic and nongenetic variation and energy sink relationships for residual feed intake across research stations and countries. J. Dairy Sci. 98:2013-2026. https://doi.org/10.3168/jds.2014.8510.

Veerkamp, R. F., J. E. Pryce, D. Spurlock, D. P. Berry, M. P. Coffey, P. Løvendahl, R. van der Linde, J. Bryant, F. Miglior, Z. Wang, M. Winters, N. Krattenmacher, N. Charfeddine, J. Pedersen, and Y. de Haas. 2013. Selection of feed intake of feed efficiency: A position paper from gDMI breeding goal discussions. Proc. Interbull Bulletin 47:15-22.

Warnes, G. R., B. Bolker, L. Bonebakker, R. Gentleman, W. H. A. Liaw, T. Lumley, M. Maechler, A. Magnusson, S. Moeller, M. Schwartz, and B. Venables. 2019. gplots: Various R programming tools for plotting data. $\mathrm{R}$ package version 3.0.1.1. https://CRAN . R-project.org $/$ package $=$ gplots.

Zetouni, L., G. F. Difford, J. Lassen, M. V. Byskov, E. Norberg, and P. Løvendahl. 2018. Is rumination time an indicator of methane production in dairy cows? J. Dairy Sci. 101:11074-11085. https:// doi.org/10.3168/jds.2017-14280.

\section{ORCIDS}

D. W. Olijhoek ( ) https://orcid.org/0000-0001-5798-3608

G. F. Difford ๑ https://orcid.org/0000-0002-6792-8722

P. Lund ๑ https://orcid.org/0000-0002-9113-4500

P. Løvendahl ๑ https://orcid.org/0000-0002-9852-2944 